Plant Production Science

http:/www.journals.zu.edu.eg/journalDisplay.aspx?Journalld=1\&queryType=Master

\title{
EFFECT OF IRRIGATION INTERVALS, ANTITRANSPIRANTS, COMPOST AND HUMIC ACID ON GROWTH AND YIELD OF SWEET POTATO
}

\author{
Hanan M. Abu El-Fotoh ${ }^{1}$, A.S. Abd-El-Kader ${ }^{2}$ and F.Y.O. Manssur ${ }^{* 2}$ \\ 1. Soil, Water and Environ. Res. Inst., Agric. Res. Cent., Egypt \\ 2. Vegetable Res. Dept., Hort. Res. Inst., Agric. Res. Cent., Egypt
}

Received: 03/03/2019 ; Accepted: 12/05/2019

\begin{abstract}
A filed experiment was carried out during two summer successive seasons of 2016 and 2017 at the Experimental Farm, El-Gemmeiza, Agric Res. Station, ARC, Gharbya Governorate (Middle Delta) Egypt, to study the effect of irrigation intervals, antitranspirant agents, soil amendments and their interactions on growth, productivity and tuber root quality of sweet potato (Buregard cv.) under Nile Delta zone conditions. The most important findings could be summarized as follows: higher values of growth traits, except number of branches/plant in $2^{\text {nd }}$ season and shoot fresh weight in the $1^{\text {st }}$ season, shoot N, P and total leaves chlorophyll contents, marketable and total yields, as well average tuber root weight were obtained due to interaction between irrigating at 12 day interval and the combined of compost + humic acid as a soil amendment. Total carbohydrates, dry matter (DM), N and $\mathrm{K}$ percentages were higher due to irrigating at 24- day interval as interacted with the combined of compost + humic acid as soil amendment, whereas total carbohydrates (\%) was higher with the interaction of 24- day irrigation interval and compost treatment (3 ton/fad.). After harvest, higher available $\mathrm{N}, \mathrm{P}$ and $\mathrm{K}$ besides $\mathrm{pH}$ and $\mathrm{E}_{\mathrm{C}}$ values were obtained under soil amendment of compost+ humic acid as interacted with either 12 or 24 - day irrigation regimes, however, differences were insignificant.
\end{abstract}

Key words: Sweet potato yield and quality, chemical constituents, irrigation interval, soil amendments, antitranspirants.

\section{INTRODUCTION}

Sweet potato (Ipomoea batatas, L.) is the seventh most important food crop worldwide, after wheat, rice, maize, potato, barley and cassava. It is the fourth most important food crop in developing tropical countries and is grown in most of the tropical and subtropical regions, and consumed by human and livestock (Woolfe, 1992). Agriculture in Egypt is almost entirely dependent on irrigation from River Nile, although there are minor contributions from groundwater. The average consumption of water for agriculture is about 58 billion $\mathrm{m}^{3} \mathrm{year}^{-1}$. Agriculture has major disadvantages over other water-consumed activities (industry, domestic and tourism etc.) due to a large percentage of

\footnotetext{
* Corresponding author: Tel. : +01280962636

E-mail address: fawzyyehya20@gamil.com
}

irrecoverable losses because of high rates of evaporation and evapotranspiration. In order to mitigate such this difficulty, agriculture has to come up with innovative ideas with respect to both cropping and irrigation water management to improve water productivity and to accomplish agriculture sustainability concepts. Soil amendments which improve soil properties and help healthy plant growth and productivity may be useful and required in this respect, Shankle et al. (2004), Saif El-Deen et al. (2011) Abdissa and Nigussie (2012), Yeng et al. (2012), Khairi et al. (2016), Naqib et al. (2016) and Abd-All et al. (2017).

Antitranspirants are the chemical compound which favours reduction in rate of transpiration from plant leaves by reducing the size and 
number of stomata and gradually hardening them to stress (Abdel-Nasser and El-Gamal, 1996; Ahmed, 2014; El-Khawaga and Mansour, 2014). Nearly $95-98 \%$ of the water absorbed by the plant is lost in transpiration (Gaballah et al., 2014). It is a substance involved in increasing drought stress resistance.

Foliar sprays markedly increase all growth parameters and relative water content and may reduce transpiration in three different ways: some chemicals reduce the absorption of solar energy and decrease leaf temperatures and transpiration rate; certain chemicals (wax, latex or plastics) form thin colourless transparent films which decrease the escape of water vapour from the leaves but not affect the gasses exchange and certain chemical compounds can control stomatal opening (by affecting the guard cells around the stomatal pore), thus decreasing the loss of water vapour from the leaves, (Besufkad and Woltering (2015). The three general types of antitranspirants are: film-forming, stomatalregulating and reflective compounds.

Foliar spraying with $2 \%$ of the dyroton as antitranspirants show very effective response in growth and yield component of plant, and it increasing the nutritional value in fruits of eggplant compared to $\mathrm{MgCO}_{3}$ and $\mathrm{K} \mathrm{SO}_{4}$. It also prevents fruits with pathogenic response after postharvest (Abd El-Aal et al., 2008). The spraying with dyroton at 3\% led to significant increase in growth characters traits, $\mathrm{N}, \mathrm{P}, \mathrm{K} \%, \mathrm{Fe}$ $\mathrm{ppm}, \mathrm{TSS} \%$, VC, firmness, fruit quality and yield as well as its components of eggplant $\mathrm{cV}$ Black Beauty compared to kaolin and $\mathrm{CaCO}_{3}$ (El-Afifi et al., 2013). The beneficial effect of antitranspirants foliar application can be arranged as follows: $\mathrm{CaCO}_{3}$ at $3 \%>$ kaolin (aluminum silicate) at $3 \%>\mathrm{K}_{2} \mathrm{SO}_{4}$ at $3 \%>$ plastic film (100\% acrylic) at $3 \%>$ mineral oil at $3 \%$ as compared with the untreated plants of cabbage cv. Balady (Ramadan and Omar, 2017).

The present research trail aiming at improving furrow-irrigated sweet potato performance via assessing different irrigation intervals, soil amendments materials and antitranspirant agents and its interaction under the circumstances of Middle Nile Delta region.

\section{MATERIALS AND METHODS}

A filed experiment was carried out during two summer successive seasons of 2016 and 2017 at the Experimental Farm, El-Gemmeiza Agric. Res. Station, ARC, Gharbya Governorate (Middle Delta, Egypt), to study the effect of irrigation intervals and both antitranspirants agents and soil amendments on growth and productivity of sweet potato (Buregard cv.) under Middle Nile Delta circumstances, Particle size distribution and some chemical analyses of the experimental soil are shown in Table 1. The present experiment included 14 treatments, which were the combinations of two irrigation intervals i.e. 12 and 24 day intervals, and three antitranspirant agents vis Kaolin at $2 \%, \mathrm{CaCO}_{3}$ at $1 \%$ and Dyroton at $2 \%$ and three soil amendments as compost at ( 3 ton/fad. $\left.{ }^{-1}\right)$, humic acid at $20 \mathrm{~kg} / \mathrm{fad}$., and the combination of compost 3 ton/fad. + humic acid at $20 \mathrm{~kg} / \mathrm{fad}$., besides the control.

The adopted irrigation intervals were represented in the main plots, while sub plots were assigned for both antitranspirant agents and soil amendments as follows:

\section{Main plots (Irrigation intervals)}

\section{2- day interval and 24- day interval}

Sub- plots (Transpiration - suppression agents and soil amendments)

Transpiration - suppression agents were:

Kaolin 2 at \%, 2- $\mathrm{CaCO}_{3}$ at $1 \%$ and 3-Dyroton at 2\%

Soil amendments were:

4- Compost, applied at 3 ton/ fad.

5- Humic acid, applied at $20 \mathrm{~kg} / \mathrm{fad}$.

6- Combined of compost at 3 ton/fad. and Humic acid at $20 \mathrm{~kg} / \mathrm{fad}$.

7- Control, neither antitranpirant agents nor soil amendments application.

The sub plot experimental unit area was $14.7 \mathrm{~m}^{2}$ containing three ridges with $7 \mathrm{~m}$ length and $70 \mathrm{~cm}$ apart. The sweet potato stem cuttings were planted on $15^{\text {th }}$ April at $20 \mathrm{~cm}$ in between in both seasons. One ridge was used to measure the morphological and chemical traits and the other two ridges were left for yield determinations. In addition, two ridges were left 
Table 1. Particle size distribution and some chemical analyses of the experimental soil

\begin{tabular}{lcc}
\hline Parameter & \multicolumn{2}{c}{ Value } \\
\hline 1. Particle size distribution* & $\mathbf{2 0 1 6}$ & $\mathbf{2 0 1 7}$ \\
Corse sand (\%) & 1.59 & 1.50 \\
Fine sand (\%) & 12.55 & 14.13 \\
Silt (\%) & 40.71 & 40.92 \\
Clay (\%) & 45.15 & 43.45 \\
Textural class & Silty clay loam & Silty clay loam \\
2. Chemical analysis* & & \\
CaCO $(\%)$ & 3.78 & 3.38 \\
Organic matter (\%) & 1.64 & 1.80 \\
Available nitrogen (ppm) & 30.0 & 31.0 \\
Available phosphorus (ppm) & 7.88 & 8.0 \\
Available potassium (ppm) & 410 & 420 \\
Soil reaction (pH) in 2.5 soil suspension & 8.0 & 8.1 \\
\hline * According to Jackson (1967) & &
\end{tabular}

as a buffer zone between each two experimental units to avoid lateral seepage of irrigation water. All the other agronomic practices recommended for sweet potato production in the area e.g. cuttings-bed preparation, N, P and $\mathrm{K}$ fertilization, weed and pest control etc., were done.

Kaolin namely $\mathrm{Al}_{2} \mathrm{Si}_{2} \mathrm{O}_{5}(\mathrm{OH})_{4}$ it containing $39.8 \%$ alumina $+46.3 \%$ silica $+13.9 \%$. Compost as botanical organic manure, it containing 51\% organic matter, $8.3 \mathrm{pH}, 2.1 \% \mathrm{~N}, 0.5 \% \mathrm{P}, 1.26 \%$ $\mathrm{K}, 1.95 \% \mathrm{Ca}, 0.96 \% \mathrm{Mg}, 1025$ ppm Fe, $115 \mathrm{ppm}$ Mn, 28 ppm Zn, 180 ppm $\mathrm{Cu}$ and 16\% other mineral constituents.

Kaolin was obtained from El-Gomhouria Co. for trading medicines, chemicals and medical appliances, Sharkia Governorate, Zagazig, Egypt.

Irrigation was started on $5^{\text {th }}$ May (15 days after planting), and ended $1^{\text {st }}$ October (15 days before harvesting) in both seasons. Under the adopted irrigation regimes, 12 and 6 irrigation events were applied under 12 and 24 days intervals, respectively throughout the entire growing season plus the planting one.

Antitranspirant agents, i.e. Kaolin, $\mathrm{CaCO}_{3}$ and Dyroton were sprayed four times in 14-day interval (started 45 days after planting) with aid a manual atomizer to accomplish thoroughly and uniform coverage of the plant's foliage, and simultaneously the untreated plants (control) were sprayed with tap water.

Compost was incorporated into the top - soil during land preparation. Humic acid was mixed with a proper soil quantity, in order to accomplish the uniform distribution, and dressed into small ditches beside each transplant just before the $1^{\text {st }}$ irrigation.

\section{Data Recorded}

A three-plant sample from each sub experimental unit was randomly taken at 110 days after transplanting to measure the plant growth traits and plant chemical constituents as follows:

\section{Plant growth traits}

a. Vine length $(\mathrm{cm})$, branches/plant and total fresh weight were measured.

b. Dry weight of shoot (Leaves and branches) of each plant were dried at $70^{\circ} \mathrm{C}$ till the constant weight and then weighed. 


\section{Plant Chemical Constituents}

\section{Photosynthetic pigments}

Total Chlorophyll content of the fourth leaf was determined according to Moran (1982) and expressed as $\mathrm{mg} / \mathrm{dc}^{2}$.

\section{Nitrogen, phosphorus and potassium contents and its uptake in shoots}

Nitrogen, phosphorus and potassium percentages in the dried shoots (leaves and branches) were determined according to AOAC (1995), and N, P and K uptake by shoots were calculated as $\mathrm{mg} /$ shoot.

Activity of amylase enzyme (as mg glucose/g dry matter/hour) in shoots, in the $2^{\text {nd }}$ season only, was determined according to Miller (1959).

\section{Yield and its components}

At harvest time (150 days after planting), all tuber roots of each treatment were classified into two grades, i.e. marketable roots $(100-250 \mathrm{~g})$ and non-marketable roots (less than $100 \mathrm{~g}$ or more than $250 \mathrm{~g}$ ), then weighed to determine the total yield which expressed as ton/fad. In addition, tuber root length, diameter and weight were determined.

It is worthy to mention that the following tuber root quality traits were determined in the second season only.

\section{Dry Matter (\%)}

One hundred grams of the grated mixture were dried at $105^{\circ} \mathrm{C}$ till the constant weight and DM (\%) was recorded.

Nitrogen, phosphorus and potassium percentages in tuber roots were determined in dry matter according to AOAC (1995).

Total carbohydrate (\%) was determined colorimetrically in dry tuber roots as (g glucose/ $100 \mathrm{~g}$ ) as outlined by Michel et al. (1956).

\section{Statistical Analysis}

Data were subjected to the statistical analysis of variance according to Snedecor and Cochran (1982), and means were compared according LSD at 5\% level.

\section{RESULTS AND DISCUSSION}

\section{Plant Growth}

\section{Effect of irrigation intervals}

Results in Table 2 show that the plant growth characters of sweet potato such as vine length, fresh and dry weights of shoot/ plant were significantly influenced by the irrigation regimes, and higher values of the abovementioned traits were found under 12-day interval by ( 6.43 and $9.39 \%),(8.21$ and $9.77 \%$ as well as 7.91 and $9.54 \%$ ) in $1^{\text {st }}$ and $2^{\text {nd }}$ seasons, respectively comparable with 24- day interval. Number of branches/plant did not significantly influenced due to the assessed irrigation regimes, however, higher figures were noticed with 12-day interval treatment in $1^{\text {st }}$ and $2^{\text {nd }}$ seasons of study. In connection, Ayoub (2005) stated that the shortest irrigation interval resulted in higher values of growth characters of sweet potato. Furthermore, Yooyongwech et al. (2014) with three sweet potato genotypes reported that net photosynthetic rate was gradually decreased as soil water content decreased.

Effect of antitranspirants and soil amendments

Results in Table 2 reveal that the tested antitranspirants and soil amendments exerted significant effect to alter the tested growth parameters in the two seasons of study. Furthermore, the assessed combination of compost + humic acid exhibited higher values of the growth parameters as compared with the other treatments, which were higher by 91.39 and $86.11 \%, 25.93$ and $22.99 \%, 77.11$ and $87.96 \%$ as well as 76.45 and $87.80 \%$ in $1^{\text {st }}$ and $2^{\text {nd }}$ seasons for vine length, number of branches/ plant as well as fresh and dry weights of shoot/ traits in respective order, comparable with the control. The present results are in accordance with those reported by Shankle et al. (2004), Saif El-Deen et al. (2011) and Abd-All et al. (2017) on sweet potato. Furthermore, sweet potato growth was significantly increased with increasing organic manure as reported by Khairi et al. (2016) and Naqib et al. (2016). In addition, results in Table 2 reveal that $\mathrm{CaCo} 31 \%$ was superior among the tested antitranspirants to exhibited higher figures of vine length and number of branches/plant traits, whereas Kaolin $2 \%$ was superior to increase fresh and dry weights of shoot, and such trends were true in $1^{\text {st }}$ and $2^{\text {nd }}$ seasons. 
Zagazig J. Agric. Res., Vol. 46 No. (3) 2019

Table 2. Effect of irrigation intervals and antitranspirants and soil amendments on sweet potato growth at 110 days from planting in 2016 and 2017 seasons

\begin{tabular}{lcccccccc}
\hline Treatment & \multicolumn{2}{c}{$\begin{array}{c}\text { Vine length } \\
\text { (cm) }\end{array}$} & \multicolumn{2}{c}{$\begin{array}{c}\text { Number of } \\
\text { branches/plant }\end{array}$} & \multicolumn{2}{c}{$\begin{array}{c}\text { Shoot } \\
\text { weight/ }\end{array}$} & plant (g) & \multicolumn{2}{c}{$\begin{array}{c}\text { Shoot dry } \\
\text { weight/plant (g) }\end{array}$} \\
\cline { 2 - 10 } & $\mathbf{2 0 1 6}$ & $\mathbf{2 0 1 7}$ & $\mathbf{2 0 1 6}$ & $\mathbf{2 0 1 7}$ & $\mathbf{2 0 1 6}$ & $\mathbf{2 0 1 7}$ & $\mathbf{2 0 1 6}$ & $\mathbf{2 0 1 7}$ \\
\hline Effect of irrigation intervals & & & & & & & \\
12- day interval & 108.71 & 104.95 & 12.54 & 10.84 & 479.37 & 431.50 & 95.78 & 86.20 \\
24- day interval & 102.14 & 95.94 & 11.59 & 10.14 & 443.00 & 393.10 & 88.76 & 78.69 \\
LSD at 5\% level & 5.83 & 6.48 & NS & NS & 21.29 & 14.19 & 4.96 & 3.54 \\
Effect of antitranspirants and soil & amendments & & & & & \\
Control & 91.39 & 86.11 & 10.72 & 9.44 & 335.00 & 286.93 & 67.12 & 57.50 \\
Kaolin at 2\% & 102.50 & 96.61 & 12.44 & 11.00 & 485.27 & 443.60 & 97.08 & 88.55 \\
CaCO3 at 1\% & 105.83 & 100.33 & 12.89 & 11.44 & 482.23 & 431.57 & 96.62 & 86.45 \\
Dyroton at 2\% & 103.61 & 98.67 & 12.06 & 10.50 & 410.57 & 359.73 & 82.20 & 71.83 \\
Humic 20 kg/fad. & 100.83 & 99.17 & 11.22 & 9.22 & 413.90 & 359.17 & 82.66 & 71.85 \\
Compost 3 ton/fad. & 114.72 & 108.61 & 11.61 & 10.22 & 508.07 & 465.27 & 101.76 & 92.98 \\
Compost + humic & 119.11 & 113.61 & 13.50 & 11.61 & 593.33 & 539.90 & 118.46 & 107.98 \\
LSD at 5\% level & 6.72 & 5.70 & 0.70 & 0.42 & 19.10 & 12.73 & 4.45 & 3.18 \\
\hline
\end{tabular}

\section{Effect of the interaction}

Results in Table 3 illustrate that the studied growth traits exhibited significant response due to the interaction of the adopted irrigation regimes as well as antitranspirants and soil amendments, such results were true in $1^{\text {st }}$ and $2^{\text {nd }}$ seasons. In general, higher values of the assessed growth traits were attained with the combination of compost at $3 \mathrm{ton} / \mathrm{fad}$. + humic at $20 \mathrm{~kg} /$ fad., under 12- day interval irrigation regime, except shoot dry weight, which exhibited higher values with humic at $20 \mathrm{~kg} / \mathrm{fad}$. + compost at 3 tonfad $^{-1}$ under 24- day interval irrigation regime, in $1^{\text {st }}$ and $2^{\text {nd }}$ seasons. In addition, Number of branches/plant resulted in different trends, where higher value in $1^{\text {st }}$ season was noticed due to Compost + Humic as interacted with12- day irrigation interval. In $2^{\text {nd }}$ season, higher value of such trait was recorded with Kaolin $2 \%$ as antitranspirant agent under 12- day irrigation interval.

\section{Chemical Shoot Constituents}

\section{Effect of irrigation regimes}

Results in Table 4 clear out that shoots mineral (N, P and $\mathrm{K}$ ) and total leaves chlorophyll contents of sweet potato did not substantially changed, however, lower values were noticed with 24 - day irrigation interval in comparison with $12-$ day irrigation one in $1^{\text {st }}$ and $2^{\text {nd }}$ seasons. In connection, Yooyongwech et al. (2014) with three sweet potato genotypes reported that net photosynthetic rate, stomatal conductance, transpiration rate and total chlorophyll were gradually decreased as soil water content decreased.

Effect of antitranspirants and soil amendments

Significant effects were exerted to alter the abovementioned parameters at 110 days from transplanting of sweet potato due to the assessed antitranspirants and soil amendments (Table 4). The combination of humic at $20 \mathrm{~kg} / \mathrm{fad}$.+ compost at 3 ton/fad., resulted in higher figures of such traits in $1^{\text {st }}$ and $2^{\text {nd }}$ seasons, compared with the other treatments. The present results may be attributed to the useful role of both humic acid and compost in improving seedling growth, root growth, and overall growth, uptake of macro- and micro-elements, bio-availability of nutrients through amendment of the soil environment at the rhizosphere (Mikkelsen, 2005; Abdel Mawgoud et al., 2007). Furthermore, Saif El-Deen et al. (2011) and Abd- All et al. (2017) reported that humic acid application enhanced growth, mineral contents, yield and its components and tuber root quality of sweet potato. In addition, Zhang $\boldsymbol{e t}$ al. (2003) found that compost materials promote the uptake of 
Table 3. Effect of the interaction between irrigation intervals and antitranspirants and soil amendments on plant growth at 110 days from planting of sweet potato in 2016 and 2017 seasons

\begin{tabular}{|c|c|c|c|c|c|c|c|c|c|}
\hline \multirow{2}{*}{$\begin{array}{l}\text { Treatment } \\
\text { Irrigation } \\
\text { Intervals } \\
\end{array}$} & \multirow[b]{2}{*}{$\begin{array}{l}\text { Antitranspirants and } \\
\text { soil amendments }\end{array}$} & \multicolumn{2}{|c|}{$\begin{array}{l}\text { Vine length } \\
\text { (cm) }\end{array}$} & \multicolumn{2}{|c|}{$\begin{array}{c}\text { Number of } \\
\text { branches/ } \\
\text { plant }\end{array}$} & \multicolumn{2}{|c|}{$\begin{array}{c}\text { Shoot fresh } \\
\text { weight/ plant } \\
\text { (g) }\end{array}$} & \multicolumn{2}{|c|}{$\begin{array}{c}\text { Shoot dry } \\
\text { weight/plant } \\
\text { (g) }\end{array}$} \\
\hline & & 2016 & 2017 & 2016 & 2017 & 2016 & 2017 & 2016 & 2017 \\
\hline \multirow{7}{*}{ 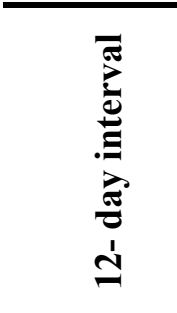 } & Control & 97.78 & 2.44 & 10.89 & 11.67 & 351.10 & 305. & 70.37 & 61.17 \\
\hline & Kao & 106. & 100.78 & 13.00 & 12.00 & 509.43 & 459.43 & 101.80 & 92.01 \\
\hline & $3_{3}$ at 1 & 107.22 & 102.89 & 13.55 & 9.11 & 498.90 & 448.90 & 99.95 & 89.97 \\
\hline & n at $2 \%$ & 106.11 & 103.00 & 12.55 & 9.11 & 426.67 & 376.67 & 85.44 & 74.85 \\
\hline & $\mathrm{kg} / \mathrm{fad}$. & 102.22 & 107.22 & 11.67 & 9.33 & 433.33 & 380.57 & 86.14 & 75.82 \\
\hline & Cor & 117.78 & 110.56 & 12.11 & 9.78 & 521.67 & 486.10 & 104.49 & 97.12 \\
\hline & Con & 123. & 117.78 & 14.00 & 9.89 & 614.43 & 563.90 & 122.24 & 112.50 \\
\hline \multirow{7}{*}{ 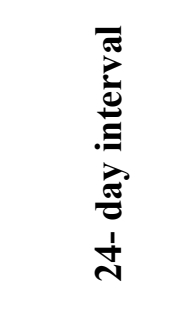 } & Col & 85.00 & 79.78 & 10.55 & 10.00 & 318.90 & 268.90 & 63.87 & 53.84 \\
\hline & Kao & 98.8 & 92.44 & 11.89 & 10.33 & 461.10 & 427.77 & 92.37 & 85.09 \\
\hline & $\mathrm{CaCO}_{3}$ & 104.44 & 97.78 & 12.22 & 10.55 & 465.57 & 414.23 & 93.29 & 82.92 \\
\hline & $2 \%$ & 101.11 & 94.33 & 11.55 & 10.89 & 394.43 & 342.77 & 78.95 & 68.82 \\
\hline & d $20 \mathrm{~kg} /$ fad. & 99.44 & 91.11 & 10.78 & 11.00 & 394.43 & 337.77 & 79.17 & 67.87 \\
\hline & //fad. & 111. & 106.67 & 11.11 & 11.55 & 494.43 & 444.43 & 99.02 & 88.85 \\
\hline & Compost +humic & 114. & 109.44 & 13.00 & 11.67 & 572.23 & 515.90 & 114.67 & 103.46 \\
\hline \multicolumn{2}{|c|}{ LSD at $5 \%$ level } & 9.60 & 8.15 & 0.99 & 0.60 & 27.02 & 18.01 & 6.30 & 4.50 \\
\hline
\end{tabular}

Table 4. Effect of irrigation intervals and antitranspirants and soil amendments on shoots mineral and total leaves chlorophyll contents at 110 days from planting of sweet potato in 2016 and 2017 seasons

\begin{tabular}{|c|c|c|c|c|c|c|c|c|c|}
\hline \multirow[t]{2}{*}{ Treatment } & \multicolumn{2}{|c|}{$\begin{array}{c}N \\
(\%)\end{array}$} & \multicolumn{2}{|c|}{$\begin{array}{l}\mathbf{P} \\
(\%)\end{array}$} & \multicolumn{2}{|c|}{$\begin{array}{l}\mathrm{K} \\
(\%)\end{array}$} & \multirow{2}{*}{$\begin{array}{c}\begin{array}{c}\text { Amylase (mg glucose } \\
\text { /g DM /hr.) }\end{array} \\
2017\end{array}$} & \multicolumn{2}{|c|}{$\begin{array}{l}\text { Total chlorophyl } \\
\text { (mg/dc. }{ }^{2} \text { DW) }\end{array}$} \\
\hline & 2016 & 2017 & 2016 & 2017 & 2016 & 2017 & & 2016 & 2017 \\
\hline \multicolumn{10}{|l|}{ Irrigation intervals } \\
\hline 12 - day interval & 2.17 & 2.56 & 0.334 & 0.381 & 2.09 & 2.40 & 15.90 & 3.56 & 3.48 \\
\hline 24 - day interval & 2.16 & 2.49 & 0.335 & 0.373 & 2.08 & 2.16 & 15.93 & 3.20 & 3.40 \\
\hline LSD at $5 \%$ level & NS & 0.05 & NS & 0.007 & NS & 0.06 & NS & 0.12 & NS \\
\hline \multicolumn{10}{|c|}{ Antitraspirants and soil amendments } \\
\hline Control & 2.00 & 2.21 & 0.312 & 0.340 & 1.84 & 1.95 & 15.06 & 3.02 & 3.06 \\
\hline Kaolin at $2 \%$ & 2.12 & 2.41 & 0.334 & 0.367 & 2.01 & 2.19 & 15.46 & 3.17 & 3.23 \\
\hline $\mathrm{CaCO}_{3}$ at $1 \%$ & 2.14 & 2.52 & 0.344 & 0.391 & 2.16 & 2.33 & 15.79 & 3.31 & 3.38 \\
\hline Dyroton at $2 \%$ & 2.16 & 2.55 & 0.338 & 0.385 & 2.10 & 2.31 & 16.00 & 3.48 & 3.49 \\
\hline Humic 20 kg/fad. & 2.19 & 2.58 & 0.336 & 0.382 & 2.12 & 2.29 & 16.07 & 3.50 & 3.58 \\
\hline Compost 3 ton/fad. & 2.21 & 2.61 & 0.331 & 0.377 & 2.09 & 2.40 & 16.44 & 3.49 & 3.56 \\
\hline Compost + humic & 2.35 & 2.77 & 0.349 & 0.398 & 2.30 & 2.54 & 16.61 & 3.72 & 3.81 \\
\hline LSD at $5 \%$ level & 0.07 & 0.16 & 0.007 & 0.022 & 0.07 & 0.19 & 0.64 & 0.08 & 0.15 \\
\hline
\end{tabular}


nutrients, increase soil moisture holding capacity, and stimulate plant growth by accelerating net photosynthesis, consequently increased plant chemical constituents.

Regarding the assessed antitraspirant agents, $\mathrm{CaCo}_{3} 1 \%$ exhibited higher values of $\mathrm{N}, \mathrm{P}$ and $\mathrm{K} \%$, whereas higher amylase activity and total leaves chlorophyll content values were attained with Dyroton at 2\%, comparable with the control, such trends were true in $1^{\text {st }}$ and $2^{\text {nd }}$ seasons. In this respect, Abdel-Nasser and ElGamal (1996) reported that application of Antitranspirants such as Kaolin at $2 \%, \mathrm{CaCO}_{3}$ at $1 \%$ and Dyroton at $2 \%$ caused significant increases in growth and yield and its components than untreated sweet potato.

\section{Effect of the interaction}

Interaction of the adopted irrigation regimes and antitraspirants and soil amendments had significant effect on N, P, K, total chlorophyll contents and amylase enzyme activity of sweet potato shoots in both seasons, except $\mathrm{P}$ and $\mathrm{K}$ contents in the $2^{\text {nd }}$ season (Table 5). It is obvious that irrigating at 24- day interval as interacted with compost + humic acid soil amendments gave higher values of N, P and K contents, in $1^{\text {st }}$ and $2^{\text {nd }}$ seasons, and amylase activity as well in $2^{\text {nd }}$ season. Total chlorophyll in leaves exhibited different trend where higher values were noticed due to 12- day irrigation interval and compost + humic acid soil amendments interaction in $1^{\text {st }}$ and $2^{\text {nd }}$ seasons. Chen et al. (2017) reported that humic acid-urea combination significantly increased nitrogen absorbed by sweet potato, compared with single $\mathrm{N}$ treatment, and reduced the loss of nitrogen fertilizer as well.

\section{N, P and K Uptake by Sweet Potato Shoot}

\section{Effect of irrigation regimes}

Results in Table 6 indicate that N, P and K uptake were significantly influenced due to the adopted irrigation regimes in $1^{\text {st }}$ and $2^{\text {nd }}$ seasons, except $\mathrm{P}$ in $1^{\text {st }}$ season. Under 12-day irrigation interval higher figures of the previously mentioned minerals were increased by 7.95 and $11.95 \%, 5.43$ and $11.39 \%$ as well as 8.49 and $20.89 \%$, respectively in $1^{\text {st }}$ and $2^{\text {nd }}$ seasons comparing with those under 24- day irrigation interval. The present results indicating that soil water status with irrigating at 12 - day interval was the proper for uptaking $\mathrm{N}, \mathrm{P}$ and $\mathrm{K}$ into sweet potato shoot, compared with 24 - day irrigation interval. In connection, Ekanayake and Collins (2004) with eight sweet potato genotypes, found that root nitrogenous compounds were significantly altered by irrigation treatments e.g. Wet (Control), intermediate, drier and very dry regimes, which induced via line-source irrigation technique.

\section{Effect of antitranspirants and soil amendments}

Furthermore, results in Table 6 illustrate that the assessed antitranspirants and soil amendments significantly altered $\mathrm{N}, \mathrm{P}$ and $\mathrm{K}$ uptake in sweet potato shoot, and such trend was true in the $1^{\text {st }}$ and $2^{\text {nd }}$ seasons. The antitranspirants and soil amendments under study resulted in higher N, P and $\mathrm{K}$ uptake values comparing with the control, and combination of compost + humic exhibited higher values, in the $1^{\text {st }}$ and $2^{\text {nd }}$ seasons, which amounted to 107.30 and $133.68 \%, 87.41$ and $118.99 \%$ as well as 121.12 and $144.14 \%$, respectively, comparing with those with the control. The obtained results are confirming the favorite effects of humic acid (Selladurai and Purakayastha 2016) and compost (Nyamangara et al., 2003) in enhancing crop performance besides improving both soil health (Chelah et al., 2011) and nutrients holding capacity (Nyamangara et al., 2003). In addition, $\mathrm{CaCO}_{3}$ $1 \%$ surpassed the other tested antitranspirant agents, in this respect, in $1^{\text {st }}$ and $2^{\text {nd }}$ seasons, comparable with the control.

\section{Effect of the interaction}

Results in Table 7 indicate that N, P and K uptake were significantly influenced due to the tested irrigation regimes and antitraspirants and soil amendments interaction, and such results were attained in the $1^{\text {st }}$ and $2^{\text {nd }}$ seasons. Higher uptake values of the abovementioned minerals were recorded with 12 - day irrigation interval as interacted with combined of compost + humic acid as a soil amendment, and the increases in $\mathrm{N}, \mathrm{P}$ and $\mathrm{K}$ uptake, in the $1^{\text {st }}$ season, reached to $171.20,89.45$ and $115.96 \%$, respectively, higher than that of the control. The corresponding increase values in the $2^{\text {nd }}$ season amounted to $112.63,107.43$ and $127.95 \%$, respectively, in the same order. 
Table 5. Effect of irrigation regimes and antitraspirants and soil amendments interaction on shoot mineral and total chlorophyll in leaves contents at 110 days from transplanting of sweet potato in 2016 and 2017 seasons

\begin{tabular}{|c|c|c|c|c|c|c|c|c|c|c|}
\hline \multirow{2}{*}{$\begin{array}{l}\text { Treatment } \\
\text { Irrigation } \\
\text { intervals }\end{array}$} & \multirow[b]{2}{*}{$\begin{array}{l}\text { Antitraspirants and soil } \\
\text { amendments }\end{array}$} & \multicolumn{2}{|c|}{$\begin{array}{c}\mathrm{N} \\
(\%)\end{array}$} & \multicolumn{2}{|c|}{$\begin{array}{c}\mathbf{P} \\
(\%)\end{array}$} & \multicolumn{2}{|c|}{$\begin{array}{c}\mathbf{K} \\
(\%)\end{array}$} & \multirow{2}{*}{$\begin{array}{c}\begin{array}{c}\text { Amylase } \\
\text { (mg }\end{array} \\
\text { glucose /g } \\
\text { DM /hr.) }\end{array}$} & \multicolumn{2}{|c|}{$\begin{array}{c}\text { Total } \\
\text { chlorophyll } \\
\text { (mg/dc. } \\
\text { DW) }\end{array}$} \\
\hline & & 2016 & 2017 & 2016 & 2017 & 2016 & 2017 & & 2016 & 2017 \\
\hline \multirow{5}{*}{ 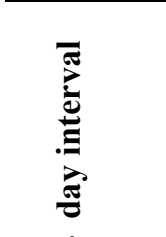 } & Control & 2.01 & 2.37 & 0.309 & 0.352 & 1.85 & 2.13 & 15.10 & 3.18 & 3.09 \\
\hline & Kaolin at $2 \%$ & 2.11 & 2.49 & 0.315 & 0.381 & 2.00 & 2.3 & 15.57 & 3.34 & 3.27 \\
\hline & $\mathrm{CaCO}_{3}$ at $1 \%$ & 2.16 & 2.55 & 0.334 & 0.392 & 2.16 & 2.48 & 15.82 & 3.47 & 3.41 \\
\hline & Dyroton at $2 \%$ & 2.17 & 2.56 & 0.334 & 0.384 & 2.11 & 2.42 & 16.03 & 3.73 & 3.54 \\
\hline & Humic 20 kg/fad. & 2.20 & 2.60 & 0.344 & 0.384 & 2.13 & 2.45 & 16.07 & 3.68 & 3.63 \\
\hline \multirow[t]{2}{*}{$\stackrel{\sim}{\simeq}$} & Compost 3 ton/fad. & 2.21 & 2.61 & 0.343 & 0.378 & 2.10 & 2.41 & 16.18 & 3.64 & 3.59 \\
\hline & Compost + humic & 2.32 & 2.74 & 0.337 & 0.397 & 2.30 & 2.64 & 16.59 & 3.88 & 3.85 \\
\hline \multirow{7}{*}{ 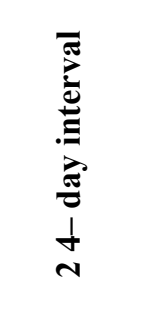 } & Control & 1.98 & 2.06 & 0.339 & 0.329 & 1.82 & 1.76 & 15.03 & 2.85 & 3.02 \\
\hline & Kaolin at $2 \%$ & 2.13 & 2.34 & 0.337 & 0.354 & 2.01 & 2.07 & 15.36 & 3.00 & 3.18 \\
\hline & $\mathrm{CaCO}_{3}$ at $1 \%$ & 2.12 & 2.50 & 0.334 & 0.391 & 2.16 & 2.18 & 15.77 & 3.15 & 3.34 \\
\hline & Dyroton at $2 \%$ & 2.15 & 2.54 & 0.332 & 0.386 & 2.08 & 2.19 & 15.98 & 3.23 & 3.43 \\
\hline & Humic 20 kg/fad. & 2.18 & 2.57 & 0.331 & 0.381 & 2.11 & 2.12 & 16.08 & 3.32 & 3.52 \\
\hline & Compost 3 ton/fad. & 2.21 & 2.61 & 0.348 & 0.377 & 2.07 & 2.38 & 16.71 & 3.33 & 3.53 \\
\hline & Compost + humic & 2.37 & 2.80 & 0.350 & 0.399 & 2.30 & 2.44 & 16.64 & 3.55 & 3.76 \\
\hline \multicolumn{2}{|c|}{ LSD at $5 \%$ level } & 0.10 & 0.23 & 0.01 & NS & 0.10 & NS & 0.91 & 0.11 & 0.22 \\
\hline
\end{tabular}

Table 6. Effect of irrigation regimes and antitranspirants and soil amendments on mineral uptake (mg/shoot) at 110 days from transplanting of sweet potato in 2016 and 2017 seasons

\begin{tabular}{|c|c|c|c|c|c|c|}
\hline \multirow[t]{2}{*}{ Treatment } & \multicolumn{2}{|c|}{$\mathbf{N}$} & \multicolumn{2}{|c|}{$\mathbf{P}$} & \multicolumn{2}{|c|}{$\mathbf{K}$} \\
\hline & 2016 & 2017 & 2016 & 2017 & 2016 & 2017 \\
\hline \multicolumn{7}{|l|}{ Irrigation intervals } \\
\hline 12 -day interval & 2087.95 & 2219.98 & 317.71 & 330.12 & 2020.02 & 2089.99 \\
\hline 24 -day interval & 1934.17 & 1983.05 & 301.36 & 296.37 & 1861.99 & 1728.81 \\
\hline LSD, 0.05 & 118.20 & 132.40 & NS & 31.20 & 118.41 & 163.20 \\
\hline \multicolumn{7}{|c|}{ Antitranspirants and soil amendments } \\
\hline Control & 1339.54 & 1279.42 & 216.98 & 196.23 & 1232.14 & 1125.25 \\
\hline Kaolin at $2 \%$ & 2057.73 & 2141.08 & 315.98 & 325.89 & 1946.32 & 1938.80 \\
\hline $\mathrm{CaCO}_{3}$ at $1 \%$ & 2068.34 & 2183.62 & 322.71 & 338.45 & 2086.99 & 2019.46 \\
\hline Dyroton at $2 \%$ & 1775.74 & 1832.09 & 273.74 & 276.53 & 1722.47 & 1659.26 \\
\hline Humic 20 kg/fad. & 1810.50 & 1857.79 & 279.19 & 274.87 & 1752.63 & 1648.22 \\
\hline Compost 3 ton/fad. & 2248.79 & 2426.91 & 351.50 & 351.04 & 2122.00 & 2227.61 \\
\hline Compost + humic & 2776.83 & 2989.69 & 406.65 & 429.72 & 2724.47 & 2747.21 \\
\hline LSD at $5 \%$ level & 92.68 & 82.91 & 28.85 & 27.41 & 88.55 & 104.42 \\
\hline
\end{tabular}


Zagazig J. Agric. Res., Vol. 46 No. (3) 2019

Table 7. Effect of irrigation intervals and antitraspirants and soil amendments interaction on shoot mineral uptake (mg) at 110 days from planting of sweet potato in 2016 and 2017 seasons

\begin{tabular}{|c|c|c|c|c|c|c|c|}
\hline \multicolumn{2}{|l|}{ Treatment } & \multicolumn{2}{|c|}{$\mathbf{N}$} & \multicolumn{2}{|c|}{$\mathbf{P}$} & \multicolumn{2}{|c|}{$\mathbf{K}$} \\
\hline $\begin{array}{l}\text { Irrigation } \\
\text { intervals }\end{array}$ & $\begin{array}{c}\text { Antitraspirants and soil } \\
\text { amendments }\end{array}$ & 2016 & 2017 & 2016 & 2017 & 2016 & 2017 \\
\hline \multirow{6}{*}{ 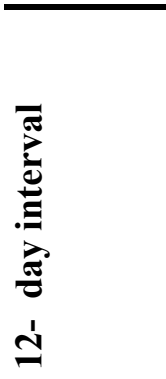 } & Control & 1414.44 & 1449.73 & 217.44 & 215.32 & 1301.85 & 1302.92 \\
\hline & Kaolin at $2 \%$ & 2147.98 & 2291.05 & 320.67 & 350.56 & 2036.00 & 2116.23 \\
\hline & $\mathrm{CaCO}_{3}$ at $1 \%$ & 2158.92 & 2294.24 & 333.83 & 352.68 & 2158.92 & 2231.26 \\
\hline & Dyroton at $2 \%$ & 1854.05 & 1916.16 & 285.37 & 287.42 & 1802.78 & 1811.37 \\
\hline & Humic 20 kg/fad. & 1895.08 & 1971.32 & 296.32 & 291.15 & 1834.78 & 1857.59 \\
\hline & Compost 3 ton/fad. & 2309.23 & 2534.83 & 358.40 & 367.11 & 2194.29 & 2340.59 \\
\hline \multirow{8}{*}{ 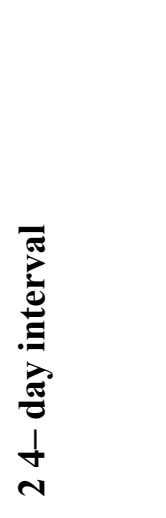 } & Compost + humic & 2835.97 & 3082.50 & 411.95 & 446.63 & 2811.52 & 2970.00 \\
\hline & Control & 1264.63 & 1109.10 & 216.52 & 177.13 & 1162.43 & 947.58 \\
\hline & Kaolin at $2 \%$ & 1967.48 & 1991.11 & 311.29 & 301.22 & 1856.64 & 1761.36 \\
\hline & $\mathrm{CaCO}_{3}$ at $1 \%$ & 1977.75 & 2073.00 & 311.59 & 324.22 & 2015.06 & 1807.66 \\
\hline & Dyroton at $2 \%$ & 1697.43 & 1748.03 & 262.11 & 265.65 & 1642.16 & 1507.16 \\
\hline & Humic 20 kg/fad. & 1725.91 & 1744.26 & 262.05 & 258.58 & 1670.49 & 1438.84 \\
\hline & Compost 3 ton/fad. & 2188.34 & 2318.99 & 344.59 & 334.96 & 2049.71 & 2114.63 \\
\hline & Compost + humic & 2717.68 & 2896.88 & 401.35 & 412.81 & 2637.41 & 2524.42 \\
\hline \multicolumn{2}{|c|}{ LSD at $5 \%$ level } & 132.40 & 118.45 & 41.22 & 39.16 & 126.51 & 149.18 \\
\hline
\end{tabular}

\section{Sweet Potato Yield and its Components}

\section{Effect of irrigation intervals}

Results in Table 8 show that there were significant effect on the tested potato yield and its components, except root diameter trait, due to the assessed irrigation regimes in $1^{\text {st }}$ and $2^{\text {nd }}$ seasons. Higher values of root weight, under 12day irrigation interval and reached to 4.92 and $4.53 \%$ in the $1^{\text {st }}$ and $2^{\text {nd }}$ seasons, respectively, higher than those recorded under 24- day irrigation interval. Root length parameter exhibited an opposite trend, where higher values were attained under 24- day irrigation interval, and amounted to 5.47 and $4.94 \%$ higher than that under 12-day irrigation interval, respectively, in $1^{\text {st }}$ and $2^{\text {nd }}$ seasons . Likely, root diameter trait exhibited the same trend, however, the differences were insignificant. As for sweet potato marketable and total yields, both parameters were significantly increased under 12- day irrigation interval by 3.57 and $4.92 \%$ as well as 5.52 and $6.44 \%$ in $1^{\text {st }}$ and $2^{\text {nd }}$ seasons, respectively, comparable with 24- day irrigation interval. In connection, Thompson et al. (1992) reported that sweet potato marketable yield increased with applied irrigation amounts until a total water application of $76 \%$ of pan evaporation (Epan) was reached. In addition, Ekanayake and Collins (2004) with eight sweet potato genotypes found that dry root yield and dry matter were attained under wet (Control) treatment as compared with intermediate, drier and very dry ones. Furthermore, Gajanayake and Reddy (2016) stated that the optimum soil moisture for storage root dry weight was obtained under the irrigation treatment $72 \%$ ET. 
Table 8. Effect of irrigation intervals and antitraspirants and soil amendments on yield and its components of sweet potato in 2016 and 2017 seasons

\begin{tabular}{lcccccccccc}
\hline Treatment & $\begin{array}{c}\text { Root weight } \\
\text { (g) }\end{array}$ & \multicolumn{2}{c}{$\begin{array}{c}\text { Root length Root diameter } \\
\text { (cm) }\end{array}$} & \multicolumn{2}{c}{$\begin{array}{c}\text { Marketable } \\
\text { (cm) }\end{array}$} & \multicolumn{2}{c}{$\begin{array}{c}\text { Total yield (ton/fad.) } \\
\text { (ton/fad.) }\end{array}$} \\
\cline { 2 - 12 } & $\mathbf{2 0 1 6}$ & $\mathbf{2 0 1 7}$ & $\mathbf{2 0 1 6}$ & $\mathbf{2 0 1 7}$ & $\mathbf{2 0 1 6}$ & $\mathbf{2 0 1 7}$ & $\mathbf{2 0 1 6}$ & $\mathbf{2 0 1 7}$ & $\mathbf{2 0 1 6}$ & $\mathbf{2 0 1 7}$ \\
\hline Irrigation intervals & & & & & & & & & \\
12- day interval & 179.42 & 208.09 & 18.28 & 20.23 & 5.61 & 5.19 & 12.880 & 12.893 & 14.036 & 14.012 \\
24- day interval & 171.01 & 199.08 & 19.28 & 21.23 & 5.77 & 5.32 & 12.436 & 12.288 & 13.302 & 13.164 \\
LSD at 5\% level & 7.21 & 6.89 & 0.35 & 0.35 & NS & NS & 0.354 & 0.283 & 0.411 & 0.508 \\
Antitraspirants and soil amendments & & & & & & & \\
Control & 178.43 & 165.30 & 16.50 & 18.16 & 6.43 & 5.93 & 9.164 & 9.526 & 10.226 & 10.746 \\
Kaolin at 2\% & 157.84 & 194.82 & 18.83 & 20.83 & 5.43 & 5.10 & 10.958 & 11.063 & 11.562 & 12.741 \\
CaCO3 at 1\% & 127.30 & 177.11 & 19.16 & 21.16 & 5.25 & 4.77 & 12.282 & 11.893 & 12.893 & 13.310 \\
Dyroton at 2\% & 187.22 & 223.94 & 21.00 & 23.00 & 5.43 & 4.93 & 13.630 & 13.223 & 14.723 & 13.733 \\
Humic 20 kg/fad. & 152.98 & 195.39 & 19.16 & 21.16 & 5.76 & 5.26 & 13.231 & 13.509 & 14.859 & 14.162 \\
Compost 3 ton/fad. 207.21 & 229.56 & 17.00 & 19.00 & 5.99 & 5.49 & 14.588 & 14.238 & 15.237 & 15.120 \\
Compost + humic & 215.53 & 238.98 & 19.83 & 21.83 & 5.53 & 5.30 & 14.753 & 14.681 & 16.181 & 15.301 \\
LSD at 5\% level & 10.56 & 8.13 & 1.23 & 1.09 & NS & NS & 0.318 & 0.254 & 0.369 & 0.456 \\
\hline
\end{tabular}

Effect of Antitraspirants and soil amendments

Results in Table 8 indicate that the adopted antitraspirants and soil amendments significantly influenced sweet potato yield and its components, except root diameter in $1^{\text {st }}$ and $2^{\text {nd }}$ seasons. The higher values of yield attributes were differentially responded with the assessed antitraspirants and soil amendments as comparaed with the control. Root weight exhibited higher values reached 11.08 and $44.57 \%$ in $1^{\text {st }}$ and $2^{\text {nd }}$ seasons, respectively, under compost + humic combination as soil amendment, higher than those with the control. Root length parameter was higher with foliar applied antitranspirant (Dyroton 2\%), and amounted to 27.27 and $26.65 \%$ in the $1^{\text {st }}$ and $2^{\text {nd }}$ seasons, respectively, higher than the control. Root diameter did not respond with the assessed antitraspirants and soil amendments, where higher figures were obtained with the control, however, the differences were insignificant in the $1^{\text {st }}$ and $2^{\text {nd }}$ seasons. Regarding marketable and total sweet potato yields, higher values were attained due to addition of compost + humic in combination, and were higher by 60.99 and $54.12 \%$ as well as 58.23 and $42.39 \%$ with marketable and total yields in the $1^{\text {st }}$ and $2^{\text {nd }}$ seasons, respectively, comparable with the control. In this respect, Chen et al. (2017) stated that humic acid - urea combination significantly increased sweet potato storage root yield, comparable with single $\mathrm{N}$ treatment.

\section{Effect of the interaction}

Results in Table 9 indicate that the tested irrigation regimes and antitraspirants and soil amendments interaction resulted in significant effects to alter sweet potato marketable and total yields and yield components, except root diameter trait, and such trend was noticed in the $1^{\text {st }}$ and $2^{\text {nd }}$ seasons. Marketable and total yields exhibited higher values due to 12- day irrigation interval and combination of compost + humic interaction in $1^{\text {st }}$ and $2^{\text {nd }}$ seasons. Additionally, root weight and root diameter traits, in the $1^{\text {st }}$ and $2^{\text {nd }}$ seasons, exhibited different trends, where the first trait resulted in higher figures with Dyroton at $2 \%$ antitranspirant under 24 day irrigation interval, whereas higher values for the second trait were obtained with interaction of 24- day irrigation interval and the control i.e. neither antitraspirants nor soil amendments were assessed. 
Zagazig J. Agric. Res., Vol. 46 No. (3) 2019

Table 9. Effect irrigation intervals and antitraspirants and soil amendments interaction on yield and its components of sweet potato in 2016 and 2017 seasons

\begin{tabular}{|c|c|c|c|c|c|c|c|c|c|c|c|}
\hline \multirow{2}{*}{$\begin{array}{c}\text { Treatment } \\
\text { Irrigation } \\
\text { intervals }\end{array}$} & \multirow[b]{2}{*}{$\begin{array}{l}\text { Antitraspirants and } \\
\text { soil amendments }\end{array}$} & \multicolumn{2}{|c|}{$\begin{array}{c}\text { Root weight } \\
\text { (g) }\end{array}$} & \multicolumn{2}{|c|}{$\begin{array}{l}\text { Root length } \\
(\mathrm{cm})\end{array}$} & \multicolumn{2}{|c|}{$\begin{array}{l}\text { Root diameter } \\
(\mathrm{cm})\end{array}$} & \multicolumn{2}{|c|}{$\begin{array}{c}\text { Marketable yield } \\
\text { (ton/fad.) }\end{array}$} & \multicolumn{2}{|c|}{$\begin{array}{l}\text { Total yield } \\
\text { (ton/fad.) }\end{array}$} \\
\hline & & 2016 & 2017 & 2016 & 2017 & 2016 & 2017 & 2016 & 2017 & 2016 & 2017 \\
\hline \multirow{7}{*}{ 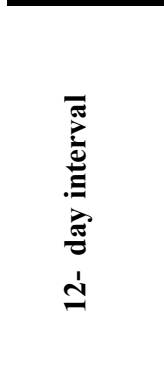 } & Control & 182.89 & 178.15 & 16.00 & 17.66 & 6.33 & 5.83 & 9.264 & 9.858 & 10.858 & 11.713 \\
\hline & Kaolin at $2 \%$ & 162.48 & 197.51 & 18.33 & 20.33 & 5.33 & 4.83 & 11.620 & 11.193 & 12.193 & 13.200 \\
\hline & $\mathrm{CaCO}_{3}$ at $1 \%$ & 131.38 & 181.14 & 18.66 & 20.66 & 5.16 & 4.67 & 12.607 & 12.160 & 13.160 & 13.433 \\
\hline & Dyroton at $2 \%$ & 191.42 & 226.46 & 20.33 & 22.33 & 5.33 & 4.83 & 13.300 & 13.809 & 14.809 & 14.020 \\
\hline & Humic 20 kg/fad. & 156.33 & 191.43 & 18.66 & 20.66 & 5.66 & 5.17 & 13.418 & 13.989 & 14.989 & 14.776 \\
\hline & Compost 3 ton/fad. & 210.52 & 235.44 & 16.33 & 18.33 & 5.97 & 5.47 & 14.759 & 14.434 & 15.434 & 15.340 \\
\hline & Compost + humic & 220.89 & 246.47 & 19.66 & 21.66 & 5.46 & 5.52 & 15.189 & 14.806 & 16.806 & 15.603 \\
\hline \multirow{7}{*}{ 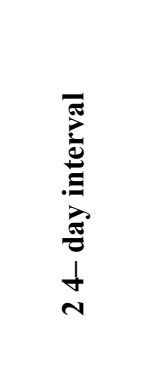 } & Control & 173.96 & 152.44 & 17.00 & 18.66 & 6.53 & 6.03 & 9.063 & 9.194 & 9.594 & 9.780 \\
\hline & Kaolin at $2 \%$ & 153.20 & 192.13 & 19.33 & 21.33 & 5.53 & 5.37 & 10.296 & 10.932 & 10.932 & 12.283 \\
\hline & $\mathrm{CaCO}_{3}$ at $1 \%$ & 123.21 & 173.09 & 19.66 & 21.66 & 5.33 & 4.88 & 11.957 & 11.626 & 12.626 & 13.187 \\
\hline & Dyroton at $2 \%$ & 183.01 & 221.41 & 21.66 & 23.66 & 5.53 & 5.03 & 13.960 & 12.637 & 14.637 & 13.447 \\
\hline & Humic 20 kg/fad. & 149.63 & 199.34 & 19.66 & 21.66 & 5.86 & 5.37 & 13.043 & 13.029 & 14.729 & 13.549 \\
\hline & Compost 3 ton/fad. & 203.90 & 223.67 & 17.66 & 19.66 & 6.01 & 5.51 & 14.417 & 14.041 & 15.041 & 14.900 \\
\hline & Compost + humic & 210.16 & 231.48 & 20.00 & 22.00 & 5.59 & 5.09 & 14.317 & 14.556 & 15.556 & 15.000 \\
\hline \multicolumn{2}{|c|}{ LSD at $5 \%$ level } & 14.93 & 11.62 & 1.74 & 1.54 & NS & NS & 0.450 & 0.360 & 0.522 & 0.645 \\
\hline
\end{tabular}

\section{Sweet Potato Tuber Roots Quality}

\section{Effect of irrigation intervals}

Results in Table 10 illustrate that higher values of DM, total carbohydrates and $\mathrm{N}, \mathrm{P}$ and $\mathrm{K}$ percentages in sweet potato tuber roots with 24 - day irrigation interval were observed, however, the effect on $\mathrm{N}$ and $\mathrm{P}$ values did not reach the significant level. Furthermore, with 24-day irrigation interval, values of DM, total carbohydrates and $\mathrm{N}, \mathrm{P}$ and $\mathrm{K}$ were increased by $18.74,5.60,9.68,2.00$ and $11.98 \%$, respectively, comparable with 12 - day irrigation interval. The present results exhibited an opposite trend to that reported by Thompson et al. (1992) who found that percentage of dry matter and total sugars contents were decreased as irrigation water reduced. In addition, Ekanayake and Collins (2004) reported that drought stress significantly reduced nitrogenous compounds, whereas root dry matter by contrast increased as water stress increased.
Effect of Antitraspirants and soil amendments

Results in Table 10 clear out that DM, total carbohydrates and $\mathrm{N}, \mathrm{P}$ and $\mathrm{K}$ percentages in sweet potato tuber roots were significantly influenced due to the assessed antitraspirants and soil amendments. Values of the abovementioned parameters, under soil amendments of compost + humic were 32.74 , $7.87,27.78,192.22$ and $29.21 \%$, respectively, higher than that of the control. In connection, Selladurai and Purakayastha (2016) and Chelah et al. (2011), respectively, illustrated the capability of humic acid in enhancing crop performance and compost in improving both soil health and nutrients holding capacity.

\section{Effect of the interaction}

Results in Table 11 indicate that the tested irrigation regimes and antitraspirants and soil amendments interaction exhibited significant effects to influence DM, Total carbohydrates and $\mathrm{N}, \mathrm{P}$ and $\mathrm{K}$ percentages of sweet potato tuber roots. Higher figures of DM, N and $\mathrm{K}$ 
Table 10. Effect of irrigation intervals and antitraspirants and soil amendments on DM, total carbohydrates, and $K$ percentages of sweet potato tuber roots in 2017 season

\begin{tabular}{|c|c|c|c|c|c|}
\hline Treatment & $\begin{array}{l}\mathrm{DM} \\
(\%)\end{array}$ & $\begin{array}{c}\text { Total carbohydrates } \\
(\%)\end{array}$ & $\begin{array}{l}\mathrm{N} \\
(\%)\end{array}$ & $\begin{array}{c}\mathbf{P} \\
(\%)\end{array}$ & $\begin{array}{c}\mathrm{K} \\
(\%) \\
\end{array}$ \\
\hline \multicolumn{6}{|c|}{ Effect of irrigation intervals } \\
\hline 12- day interval & 17.77 & 57.81 & 1.55 & 0.249 & 1.92 \\
\hline 24- day interval & 21.10 & 61.05 & 1.70 & 0.254 & 2.15 \\
\hline LSD at $5 \%$ level & 1.06 & 0.70 & NS & NS & 0.09 \\
\hline \multicolumn{6}{|c|}{ Effect of antitraspirants and soil amendments } \\
\hline Control & 17.52 & 57.43 & 1.44 & 0.144 & 1.78 \\
\hline Kaolin at $2 \%$ & 17.67 & 58.53 & 1.49 & 0.229 & 1.91 \\
\hline $\mathrm{CaCO}_{3}$ at $1 \%$ & 18.75 & 58.29 & 1.62 & 0.243 & 1.98 \\
\hline Dyroton at $2 \%$ & 19.39 & 59.05 & 1.60 & 0.229 & 2.00 \\
\hline Humic 20 kg/fad. & 19.95 & 59.00 & 1.62 & 0.294 & 2.06 \\
\hline Compost 3 ton/fad. & 21.11 & 61.78 & 1.76 & 0.300 & 2.22 \\
\hline Compost + humic & 21.68 & 61.95 & 1.84 & 0.321 & 2.30 \\
\hline LSD at $5 \%$ level & 0.95 & 0.63 & 0.11 & 0.009 & 0.08 \\
\hline
\end{tabular}

Table 11. Effect of irrigation intervals and antitraspirants and soil amendments interaction on DM, total carbohydrates, N, P and K percentages of sweet potato tuber roots in 2017 season

\begin{tabular}{|c|c|c|c|c|c|c|}
\hline \multicolumn{2}{|l|}{ Treatment } & \multirow{2}{*}{$\begin{array}{l}\text { DM } \\
(\%)\end{array}$} & \multirow{2}{*}{$\begin{array}{c}\text { Total } \\
\text { carbohydrates } \\
(\%)\end{array}$} & \multirow{2}{*}{$\begin{array}{l}\mathbf{N} \\
(\%)\end{array}$} & \multirow{2}{*}{$\begin{array}{l}\mathbf{P} \\
(\%)\end{array}$} & \multirow{2}{*}{$\begin{array}{c}\mathrm{K} \\
(\%)\end{array}$} \\
\hline Irrigation intervals & $\begin{array}{c}\text { antitraspirants and soil } \\
\text { amendments }\end{array}$ & & & & & \\
\hline \multirow{9}{*}{ 12- day interval } & Control & 16.25 & 54.95 & 1.31 & 0.146 & 1.69 \\
\hline & Kaolin at $2 \%$ & 16.61 & 56.90 & 1.28 & 0.228 & 1.78 \\
\hline & $\mathrm{CaCO}_{3}$ at $1 \%$ & 17.40 & 56.25 & 1.53 & 0.240 & 1.87 \\
\hline & Dyroton at $2 \%$ & 17.85 & 57.13 & 1.54 & 0.213 & 1.81 \\
\hline & Humic 20 kg/fad. & 17.81 & 57.53 & 1.58 & 0.296 & 1.91 \\
\hline & Compost 3 ton/fad. & 19.07 & 60.61 & 1.79 & 0.298 & 2.18 \\
\hline & Compost + humic & 19.46 & 61.34 & 1.84 & 0.322 & 2.26 \\
\hline & Control & 18.79 & 59.92 & 1.57 & 0.143 & 1.87 \\
\hline & Kaolin at $2 \%$ & 18.74 & 60.17 & 1.71 & 0.230 & 2.05 \\
\hline \multirow{5}{*}{ 24- day interval } & $\mathrm{CaCO}_{3}$ at $1 \%$ & 20.10 & 60.34 & 1.71 & 0.246 & 2.09 \\
\hline & Dyroton at $2 \%$ & 20.93 & 60.97 & 1.66 & 0.246 & 2.20 \\
\hline & Humic 20 kg/fad. & 22.09 & 60.48 & 1.67 & 0.292 & 2.22 \\
\hline & Compost 3 ton/fad. & 23.16 & 62.95 & 1.73 & 0.303 & 2.27 \\
\hline & Compost + humic & 23.90 & 62.57 & 1.85 & 0.321 & 2.35 \\
\hline LSD at $5 \%$ level & & 1.35 & 0.90 & 0.15 & 0.013 & 0.11 \\
\hline
\end{tabular}


percentages were attained due to combined compost + humic acid (soil application) under 24- day irrigation interval, and the values were increased by $47.08,41.22$ and $39.05 \%$, respectively, comparable with the control. Total carbohydrates $(\%)$ recorded higher value under 24- day irrigation interval and compost at 3 ton/fad.' interaction, however, the difference was insignificant when compared with that under 24day irrigation interval and compost at 3 ton/fad., rate. Likely, $\mathrm{P} \%$ exhibited higher value due to interaction of 12- day irrigation interval and combined compost + humic acid, which did not significantly varied comparing with that under 24- day irrigation interval and compost at 3 ton/fad., interaction.

\section{Some Soil Chemical Characteristics After Harvesting}

\section{Effect of irrigation regimes}

Results in Table 12 indicate that the adopted irrigation regimes did not appreciably influenced the chemical soil characteristics after harvesting of sweet potato tuber yield.

\section{Effect of antitraspirants and soil amendments}

Available soil N, P and $\mathrm{K}$ exhibited higher values due to soil- applied compost + humic acid amounted to $36.31,44.47$ and $16.33 \%$, respectively, comparable with the control. In

Table 12. Effect of irrigation intervals and antitraspirants and soil amendments and their interaction on some chemical soil properties after harvesting (average two seasons)

\begin{tabular}{|c|c|c|c|c|c|c|}
\hline \multicolumn{2}{|l|}{ Treatment } & $\begin{array}{c}\text { Available N } \\
\text { (ppm) }\end{array}$ & $\begin{array}{c}\text { Available } P \\
\text { (ppm) }\end{array}$ & $\begin{array}{c}\text { Available K } \\
\text { (ppm) }\end{array}$ & pH & $\begin{array}{c}\mathrm{EC} \\
\left(\mathrm{dSm}^{-1}\right)\end{array}$ \\
\hline \multicolumn{7}{|c|}{ Effect of irrigation regimes } \\
\hline \multicolumn{2}{|c|}{ 12- day interval } & 42.45 & 9.65 & 481.28 & 8.20 & 0.33 \\
\hline \multicolumn{2}{|c|}{ 24- day interval } & 42.62 & 9.61 & 480.95 & 8.18 & 0.33 \\
\hline \multicolumn{7}{|c|}{ Effect of antitraspirants and soil amendments } \\
\hline \multicolumn{2}{|c|}{ Control } & 37.46 & 8.05 & 442.84 & 7.98 & 0.25 \\
\hline \multicolumn{2}{|c|}{ Kaolin at $2 \%$} & 40.71 & 9.57 & 465.50 & 8.18 & 0.34 \\
\hline \multicolumn{2}{|c|}{$\mathrm{CaCO}_{3}$ at $1 \%$} & 41.98 & 9.54 & 486.83 & 8.22 & 0.32 \\
\hline \multicolumn{2}{|c|}{ Dyroton at $2 \%$} & 43.55 & 9.55 & 486.17 & 8.16 & 0.32 \\
\hline \multicolumn{2}{|c|}{ Humic 20 kg/fad. } & 42.38 & 9.65 & 482.84 & 8.32 & 0.34 \\
\hline \multicolumn{2}{|c|}{ Compost 3 ton/fad. } & 40.39 & 9.10 & 467.83 & 8.14 & 0.35 \\
\hline \multicolumn{2}{|c|}{ Compost + humic } & 51.06 & 11.63 & 515.17 & 8.36 & 0.43 \\
\hline \multicolumn{7}{|c|}{ Effect of interaction } \\
\hline & Control & 37.67 & 8.06 & 441.00 & 7.96 & 0.25 \\
\hline \multirow{6}{*}{$\begin{array}{l}\text { 12- day } \\
\text { irrigation } \\
\text { interval }\end{array}$} & Kaolin at $2 \%$ & 40.53 & 9.74 & 486.33 & 8.21 & 0.34 \\
\hline & $\mathrm{CaCO}_{3}$ at $1 \%$ & 41.65 & 9.60 & 486.33 & 8.22 & 0.29 \\
\hline & Dyroton at $2 \%$ & 43.70 & 9.63 & 486.33 & 8.18 & 0.32 \\
\hline & Humic 20 kg/fad. & 42.27 & 9.78 & 482.67 & 8.31 & 0.33 \\
\hline & Compost 3 ton/fad. & 40.16 & 9.13 & 471.33 & 8.16 & 0.36 \\
\hline & Compost + humic & 51.15 & 11.61 & 515.00 & 8.36 & 0.43 \\
\hline \multirow{7}{*}{$\begin{array}{l}\text { 24- day } \\
\text { irrigation } \\
\text { interval }\end{array}$} & Control & 37.24 & 8.04 & 444.67 & 8.00 & 0.24 \\
\hline & Kaolin at $2 \%$ & 40.88 & 9.40 & 487.33 & 8.14 & 0.33 \\
\hline & $\mathrm{CaCO}_{3}$ at $1 \%$ & 42.30 & 9.47 & 486.00 & 8.21 & 0.35 \\
\hline & Dyroton at $2 \%$ & 43.40 & 9.68 & 486.00 & 8.14 & 0.32 \\
\hline & Humic 20 kg/fad. & 42.49 & 9.95 & 483.00 & 8.33 & 0.34 \\
\hline & Compost 3 ton/fad. & 40.62 & 9.06 & 464.33 & 8.11 & 0.33 \\
\hline & Compost + humic & 50.97 & 11.64 & 515.33 & 8.35 & 0.43 \\
\hline
\end{tabular}


connection, Bryan and Stark (2003) and Mikkelsen (2005) reported that humic acid improved bio-availability of nutrients through amendment of the soil environment at the rhizosphere. Furthermore, compost addition resulted in improved nutrients holding capacity (Nyamangara et al., 2003).

\section{Effect of the interaction}

Results in Table 12 indicate that higher available $\mathrm{N}, \mathrm{P}$ and $\mathrm{K}$ besides $\mathrm{pH}$ and $\mathrm{EC}$ values under soil amendment of compost + humic acid as interacted with either 12 or 24 - day irrigation regimes did not significantly differed, which could be attributed to the potency of humic acid to increase nutrient availability and to compost in improving soil health via enhancing soil nutrient holding capacity. Such interpretation was previously stated by Chelah et al. (2011) and Selladurai and Purakayastha (2016).

\section{REFERENCES}

Abd- All, A.E., A.E. El-Namas and E.M. ElNaggar (2017). Effect of humic acid and foliar application of different potassium sources on yield, quality and water use efficiency of sweet potato grown under drip irrigation in sandy soil. Alex. Sci. Exchange J., 38 (3): 543-552.

Abd El-Aal, F.S., M.M. Abdel Mouty and A.H. Ali (2008). Combined effect of irrigation intervals and foliar application of some antitranspirants on eggplant growth, fruits yield and its physical and chemical properties. Res. J. Agric. Biol. Sci., 4 (5): 416- 423.

Abdel Mawgoud, A., M.R.N. El-Greadly, Y.I. Helmy and S.M. Singer (2007). Responses of tomato plants to different rates of humic based fertilizer and NPK fertilization. J. Appl. Sci. Res., 3: 169-174.

Abdel-Nasser, G. and A.M. El-Gamal (1996). Effects of film-forming antitranspirant (folicote) on water status, growth and yield of sweet potato (Ipomoea batatas L.)." In Proc. $4^{\text {th }}$ Arab Conf. Hort. Crops, Egypt.

Abdissa, T.M. and D.R. Nigussie (2012). Yield and yield components of sweet potato as affected by Farmyard manure and Phosphorus application: in the case of Adami Tulu District, Central Rift Valley of Ethiopia. Basic Res. J. Agric. Sci. and Rev., 1 (2): 3142.

Ahmed, Y.M.A. (2014). Impact of Spraying Some Antitranspirants on Fruiting of Williams Bananas Grown Under Aswan Region Conditions. Stem Cell., 5(4) : 34-39.

AOAC (1995). Association of Official Agricultural Chemists. Official Methods of Analysis. $10^{\text {th }}$. Ed. AOAC, Wash., DC.

Ayoub, I.I. (2005). Effect of fertigation and plant population on growth, yield and storability of sweet potato grown under sandy soil conditions. Ph.D. Thesis, Fac. Agric., Zagazig Univ., Egypt.

Besufkad, A. and E. Woltering (2015). Ethylene, 1-MCP and the anti-transpirant effect of active compound-film forming blend. J. Hort., 2 : 153 .

Bryan, H. and J. Stark. (2003). Humic acid effects on potato response to phosphorus. Idaho Potato Conf., USA, Jan. 22-23, 5.

Chelah, M.K.B., M.N. Nozulaidi, M.I. Musliania, Y.M. Khanif and M.S. Jahan (2011). Composting increases BRIS soil health and sustains rice production on BRIS Soil. Sci. Asia, 37 : 291-295.

Chen, X.G., M. Kou, Z.H. Tang, A.J. Zhang and H.M. Li (2017). The use of humic acid urea fertilizer for increasing yield and utilization of nitrogen in sweet potato. Plant Soil Environ., 63: 201-206.

Ekanayake, I. J. and W. Collins (2004). Effect of irrigation on sweet potato root carbohydrates and nitrogenous compounds. Food, Agric. and Environ., 2 (1): 243-248.

El-Afifi, S. T. M., Hala A. El-Sayed g S. M. Farid and A. A. Shalata (2013). Effect of organic fertilization, irrigation intervals and some antitranspirants on growth and productivity of eggplant (Solanum melongina L.). J. Plant Production, Mansoura Univ., 4 (2): 271 - 286.

El-Khawaga, A.S. and A.E.M. Mansour (2014). Enhancing the efficiency of irrigation water use by using some antitranspirants in wounderful pomegranate orchards. Middle East J. Agric. Res., 3(3): 694-700. 
Gaballah, M.S., S.M. Shaaban and E.F. Abdallah (2014). The use of antitranspirants and organic compost in sunflower grown under water stress and sandy soil. Int. J. Acad. Res., 6.

Gajanayake, B. and K.R. Reddy (2016). Sweet potato responses to mid- and late-season soil moisture deficits. Crop Sci., 56 (4): 1865 1877.

Khairi, M., M. Nozilaudi, A.M. Sarmila, S.A. Naqib and S.M.D. Jahan (2016). Compost and zinc application enhanced production of sweet potatoes in sandy soil. J. Agric. Res., 1 (2): $1-8$.

Michel, K., J.K. Gilles, P.A. Hamilton and F. Smith (1956). Colorimetric method for determination of sugars and related substances. Anal. Chem., 28 (3): 350.

Mikkelsen, R.L. (2005). Humic materials for agriculture. Better Crops, 89 (3): 6-10.

Miller, G.L. (1959). Use of dintro salicylic acid regent for determination of reducing sugars. Anal. Chem., 31:426-428.

Moran, R. (1982). Formula for determination of chlorophylls Pigments extracted with NN. dimethyl formaide. Plant Physiol., 69 : 13761381.

Naqib, S.A., W.N. Khairunisha, M. Khairi and M. Nozulaidi (2016). Copper and compost induced sweet potatoes production in sandy soil. J. Agric. Vet. Sci., 9(9): 85-90.

Nyamangara, J., L.F. Bergstrom, M.I. Piha and K.E. Giller (2003). Fertilizer use efficiency and nitrate leaching in a tropical sandy soil. J. Eniviron. Qual., 32: 599-606.

Ramadan A. Y. and M. M. Omar (2017). Effect of water regime and antitranspirants foliar on production and yield of cabbage in summer season. Egypt. J. Soil Sci., 57 (4): $467-476$
Saif El-Deen, U.M., A.S. Ezzat and A.H.A. ElMorsy (2011). Effect of phosphorus fertilizer rates and application methods of humic acid on productivity and quality of sweet potato. J. Plant Prod., Mansoura Univ., 2 (1): 53 66.

Selladurai, R. And T.J. Purakayastha (2016). Effect of humic acid multinutrient fertilizers on yield and nutrient use efficiency of potato. J. Plant Nutr., 39: 949-956.

Shankle, M.W., T.F. Garrett and J.L. Main. (2004). Humic acid nutrient trial. Mississippi Agric. and Forestry Exp. Station Inform. Bulletin, 405: 218-219.

Snedecor, G.W. and W.G. Cochran (1982). Statistical Methods. $7^{\text {th }}$ Ed. $2^{\text {nd }}$ Printing, Iowa State. Univ. Press, Ame., USA, 507.

Thompson, P.G., D.A. Smittle and M.R. Hall (1992). Relationship of sweet potato yield and quality to amount of irrigation. Hort. Sci., 27(1): $23-26$

Woolfe, J.A. (1992). Sweet potato: an untapped food resource. New York: Camb. Univ. Press.

Yeng, S.B., K. Agyarko, H.K. Dapaah, W.J. Adomako and E. Asare (2012). Growth and yield of sweet potato (Ipomoea batatas L.) as influenced by integrated application of chicken manure and inorganic fertilizer. Afr. J. Agric. Res., 7: 5387-5395.

Yooyongwech, S., T. Samphumphuang, C. Theerawitaya and S. Cha-um (2014). Physiomorphological responses of sweet potato [Ipomoea batatas (L.) Lam.] genotypes to water-deficit stress. POJ, 7 (5): 361-368.

Zhang, X., E.H. Ervin and R.E. Schmidt (2003). Physiological effects of liquid applications of a seaweed extract and a humic acid on creeping bentgrass. J. Ame. Soc. Hort. Sci., 128 (4): 492-496. 
تأثير فترات الري، مضادات النتح، الكمبوست وحمض الهيومك على النمو والمحصول في البطاطا

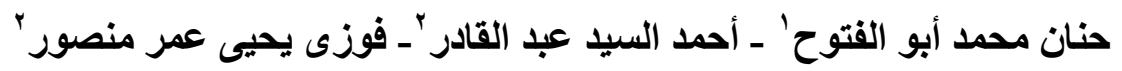

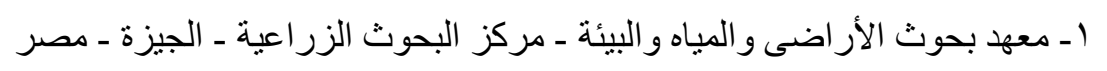

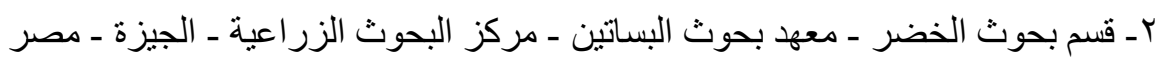

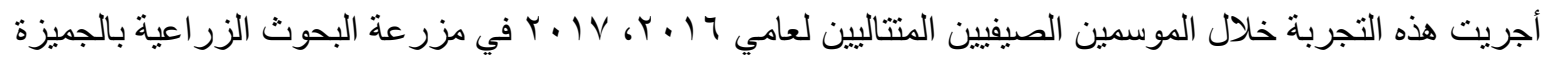

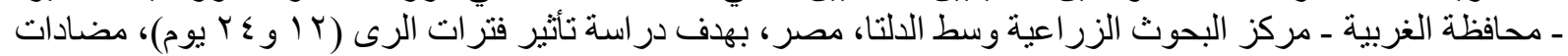

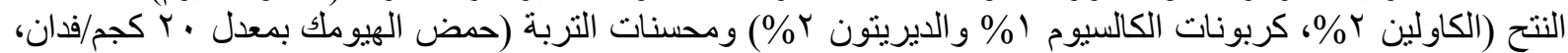

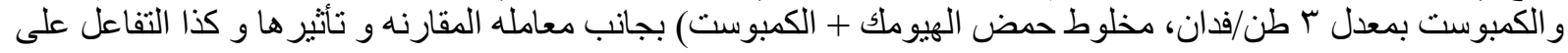

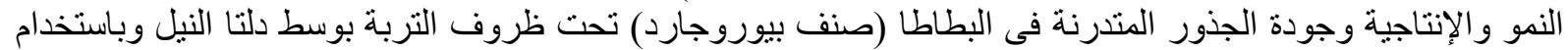

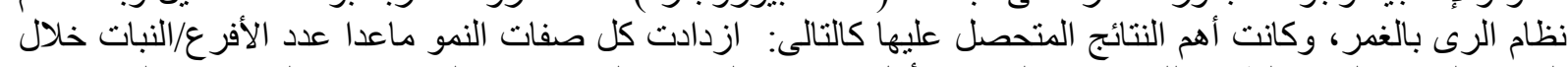

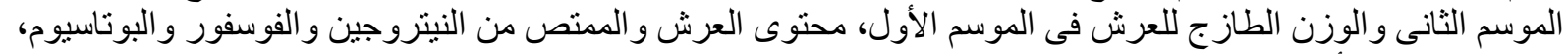

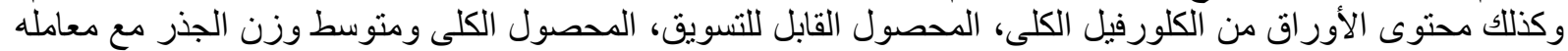

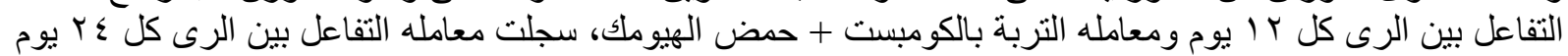

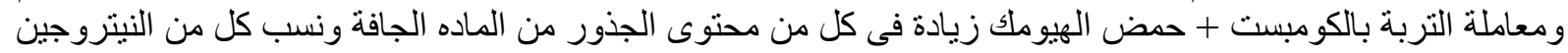

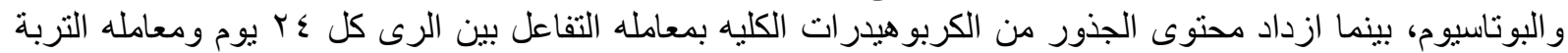

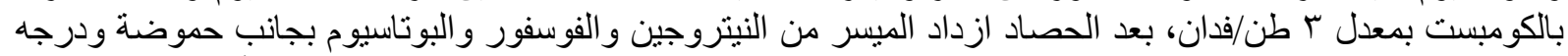

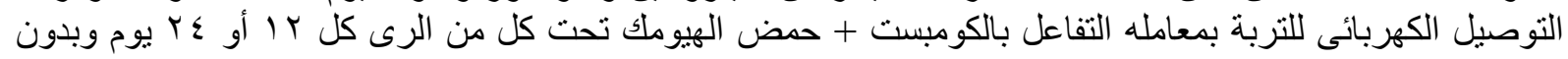
فروق معنوية بينهما. 